$4{ }^{1}$ Department of Geography, University of California, Santa Barbara, CA, USA. ORCID iD: 0000-0003$5 \quad 1670-8567$

$6 \quad{ }^{2}$ Earth Research Institute, University of California, Santa Barbara, CA, USA

$7 \quad{ }^{3}$ Department of Environmental Sciences, Rutgers, The State University of New Jersey, NJ, USA

8 Corresponding author: Marcia T Zilli (marciatz@gmail.com), Department of Geography, 1832 Ellison

9 Hall, University of California, Santa Barbara, CA. 93106-4060 Phone: +1 (805) 637-7806.

\section{The poleward shift of South Atlantic Convergence Zone in recent decades}

\begin{abstract}
During austral summer (December-January-February or DJF), intense precipitation over central-eastern Brazil is modulated by the South American Monsoon System and the South Atlantic Convergence Zone (SACZ). Previous studies identified spatial variability in precipitation trends over this region, suggestive of a poleward shift of the SACZ in recent years. To identify underlying mechanisms associated with changes in the precipitation intensity and position of the SACZ, decadal averages of observed precipitation and the mean state of the atmosphere and ocean during three different periods from 1979 to 2014 are compared. Results show evidence of decreasing (increasing) average daily precipitation along the equatorward (poleward) margin of the climatological SACZ, likely related to a poleward shift of the convergence zone. Precipitation reduction along the equatorward margin of the SACZ is associated with weakening of the poleward winds along the eastern Brazilian coast and drying of low-to-mid troposphere $(700 \mathrm{hPa})$ over the tropical Atlantic. These changes in circulation and moisture are likely related to the poleward expansion of the South Atlantic Subtropical High.
\end{abstract}

Keywords: South Atlantic Convergence Zone; precipitation; convective margin; decadal variability; South America 
Persistent and intense precipitation characterizes the austral summer season (December-JanuaryFebruary, DJF) in central-eastern and southeastern Brazil, with summertime rainfall accounting for more than $50 \%$ of the annual total there (Liebmann et al. 2001; Barros et al. 2000; Vera et al. 2006). Precipitation in these regions is influenced by both the South American Monsoon System (SAMS) and the South Atlantic Convergence Zone (SACZ; Zhou and Lau 1998; Barros et al. 2000; Zhou and Lau 2001; Carvalho et al. 2004, 2011; Vera et al. 2006; Muza et al. 2009).

The SACZ, which is one of the main features of the SAMS (Kodama 1992, 1993; Zhou and Lau 1998; Liebmann et al. 2001; Carvalho et al. 2002, 2004; Marengo et al. 2012), comprises a diagonallyoriented band of deep convection extending from tropical South America (SA) southeastward toward southeastern (SE) Brazilian coast and into the subtropical South Atlantic Ocean. Kodama (1992, 1993) described the SACZ as a baroclinic structure located to the east of a trough in the subtropical jet. It is formed by moisture converging from two different regions: low-level poleward (northerly) inflow originating along the western periphery of the South Atlantic Subtropical High (SASH); and westerly flows along the convergence zone, increasing in intensity with height and forming part of the subtropical jet in upper levels. These two components are thought to be essential for the development and strengthening of the SACZ through frontogenesis and convective instability generation (Kodama 1993).

The spatial variability of spring and summer (September-February) precipitation over SA is dominated by a dipole-like pattern of opposing anomalies over central-eastern Brazil (CEBr) and southeastern SA (SESA) occurring across multiple timescales (Zhou and Lau 1998; Nogués-Paegle et al. 2000; Carvalho et al. 2002; Grimm and Zilli 2009; Carvalho et al. 2011; Grimm and Saboia 2015). From spring to summer, this dipole switches polarity whenever the antecedent soil moisture conditions are favorable (Grimm et al. 2007; Grimm and Zilli 2009). Grimm and Saboia (2015) showed that this is also observed on decadal time scales and is partially influenced by large scale climate modes of variability, such as the Interdecadal Pacific Oscillation (IPO) and the Atlantic Multidecadal Oscillation (AMO). Additionally, the positive phase of the El Nino/Southern Oscillation (ENSO) has been related to above average precipitation in January over CEBr (e.g., Grimm 2003; Drumond and Ambrizzi 2006; Grimm et al. 2007; Krishnamurthy and Misra 2010) and to a persistent oceanic SACZ (Carvalho et al. 2004), which increases the probability of extreme rainfall events over coastal SE Brazil (Carvalho et al. 2002; Liebmann et al. 2001).

On interannual and interdecadal time scales, the position and intensity of the SACZ is also modulated by the South Atlantic Dipole (SAD). The SAD is a coupled atmosphere-ocean mode characterized by changes in the SASH intensity, which forces sea surface temperature (SST) anomalies of opposite sign over the tropical and subtropical South Atlantic (Venegas et al. 1997; Robertson and Mechoso 2000; Barreiro et al. 2002; Wainer and Venegas 2002; Bombardi et al. 2013). Bombardi et al. (2013) showed that during negative SAD phases, negative (positive) SST anomalies over tropical (subtropical) South Atlantic are related to the enhancement of the westerly winds over CEBr, with the associated increase of cyclonic moisture transport enhancing precipitation over this region. In turn, SST 
variability over the southwestern subtropical South Atlantic appears to be related to SACZ internal variability, with positive (negative) precipitation anomalies over the SACZ, particularly its oceanic portion, increasing (reducing) cloudiness and resulting in negative (positive) SST anomalies over the region (Barros et al. 2000; Grimm and Zilli 2009; Talento and Barreiro 2012).

Thus, both SACZ and South Atlantic SST variability are modulated by the position and intensity of the SASH. Li et al. (2013) demonstrated that the SASH has become more intense in recent years, which may be a regional manifestation of the observed poleward expansion of the Hadley circulation (Chen et al. 2014). Similar behavior is also evident in present and future scenarios of climate change as simulated by climate models (Seidel and Randel 2007; Vecchi and Soden 2007; Lu et al. 2007; Schneider et al. 2010; Li et al. 2013; Chen et al. 2014), suggesting that this trend will likely persist in the future. Climate change projections indicate that future intensification of the SASH could shift the SACZ poleward (Seth et al. 2010), favoring the occurrence of positive (negative) precipitation anomalies over SESA (CEBr), with a spatial pattern analogous to the negative phase of the SACZ dipole (Junquas et al. 2012; Talento and Barreiro 2012; Jones and Carvalho 2013; Diaz and Vera 2017). Talento and Barreiro (2017) used an Atmospheric General Circulation Model (AGCM) forced with idealized heat sources over the Northern Hemisphere and demonstrated relationships between changes in the Hadley circulation, the intensification of the SASH, and consequent enhancement of subsidence over the tropical South Atlantic. Additionally, studies based on a two-way nesting climate model (model with a finer resolution region nested in a global climate model) forced with projected changes in SST showed that positive (negative) precipitation trends over SESA (CEBr) are related to enhanced (weakened) convergence as part of a propagating Rossby wave train forced by asymmetric warming over the Indian and equatorial western Pacific oceans (Junquas et al. 2013).

In fact, the observed spatial pattern of precipitation trends over SA in recent decades is consistent with climate model projections. Previous studies identified an increase in total precipitation over SESA, mostly related to both an increase in the number of intense events as well as a decrease in the number of consecutive dry days over the region (Haylock et al. 2006; Barros et al. 2008; Skansi et al. 2013). Zilli et al. (2016) showed that extreme rainfall events have become more intense and frequent during the rainy season over the northern part of the $\mathrm{CEBr}$ region in recent decades, although the number of rainy days (days with precipitation above $1 \mathrm{~mm} /$ day) is decreasing. Over the southern portion of the region CEBr, Zilli et al. (2016) identified an increase in total precipitation related to an increase in rainy days and more frequent and intense extreme events and speculated that the spatial variability of the observed trends in extreme precipitation over coastal SE Brazil could be explained by a poleward shift of the SACZ.

The present study investigates decadal changes in the circulation features related to the position and intensity of the SACZ that could influence dynamic and thermodynamic processes related to precipitating deep convection over central-eastern Brazil and adjacent South Atlantic Ocean. This study also explores possible mechanisms through which tropospheric warming may influence large-scale circulation in the region. The discussion is organized as follows: dataset and methodology are described in Section 2. Changes in decadal mean state of the atmosphere during DJF, including changes in 
1 precipitation, circulation and temperature, are presented in Section 3. Section 4 discusses the implications

2 of large scale changes on regional precipitation, while in Section 5 we summarize the results and present conclusions.

\section{Data and Methods}

\subsection{Data}

The precipitation dataset used in this study is the monthly gridded data from the Global Precipitation Climatology Project Version 2.2 (GPCP; Huffman et al. 2009). It has $2.5^{\circ}$ lon/lat horizontal resolution, spanning 1979 to 2015, and combines rain gauge and satellite precipitation estimates. Changes in the basic state of the atmosphere are evaluated with the National Center for Environmental Prediction (NCEP) Climate Forecast System Reanalysis (CFSR; Saha et al. 2010), at a spatial resolution of $0.5^{\circ}$ lon/lat and daily temporal resolution, from 1979 to 2015. The atmospheric fields investigated are: geopotential height at $200 \mathrm{hPa}(\mathrm{Z} 200)$, vertical velocity at $500 \mathrm{hPa}(\omega 500)$, specific humidity at $700 \mathrm{hPa}$ (Q700) and 850 (Q850), wind and temperature at $850 \mathrm{hPa}$ (Wind850 and T850, respectively), and sea level pressure (SLP). Sea surface temperatures (SSTs) are derived from the National Oceanic and Atmospheric Administration (NOAA) Optimum Interpolation (OI) SST Version 2 High Resolution dataset (Reynolds at al. 2007), with daily data since 1981 at spatial resolution of $0.25^{\circ}$ lon/lat. The same analysis was repeated using the European Reanalysis Interim (ERAI) from the European Centre for Medium-Range Weather Forecasts (Dee et al. 2011) and reconstructed SST from the Hadley Centre (HadISST; Rayner et al. 2003), with similar results (see Online Supplementary Material).

\subsection{Methods}

Changes in the mean DJF precipitation rate and in the basic state of other atmospheric fields over SA were estimated by comparing the austral summer averages for three 10-year periods. Since ENSO is the most important coupled mode of variability influencing precipitation in SA (e.g. Grimm, 2003; Grimm et al. 2007), the 10-year periods were determined after excluding strong ENSO events. These strong ENSO events were identified when the absolute values of the Oceanic Niño Index (ONI, available at http://www.cpc.ncep.noaa.gov/products/analysis_monitoring/ensostuff/ensoyears.shtml) were greater than $1.4^{\circ} \mathrm{C}$ for at least three consecutive 3-month running means, as long as these conditions were satisfied in at least one month in DJF. Thus, the resultant periods were: 1979-1991 (excluding 1982-83 El Niño, 1988-89 La Niña, and 1991-92 El Niño); 1992-2004 (excluding 1997-98 El Niño, 1998-99, and 1999-2000- both La Niña); and 2005-2014 (no strong ENSO events). The exact choice of years for each period as well as the length of these periods did not affect the final results. Furthermore, the inclusion of ENSO years did not change the final results despite small variations in the magnitude of the difference of specific variables and regions. However, we decided to remove those years due to the large number of strong ENSO events during the 80's and 90's. Because the SST dataset begins in 1981, the first period 
considered when investigating changes in the mean SST conditions in this analysis spans 1981-1992 and the second period 1993-2004, excluding the same number of ENSO years. The years considered in each period and dataset and the years excluded due to ENSO events are summarized in Table 1. Notice that the DJF average of a variable for a specific year is calculated using December of that year and January and February of the next year.

To identify decadal changes in the mean basic state of the atmosphere during DJF, we compared the averages for the period 1979-1991 with those for 2005-2014. Since we used all daily values for each period (900 days), the null hypothesis of the averages over two periods being equal was tested using a $z$ test considering two independent samples, at 5\% significance level, according to a Student's t-distribution (Wilks, 2011). The degrees of freedom were assessed based on the effective sample size of each grid point, after accounting for serial autocorrelation (Wilks, 2011).

Changes in SLP were based on the zonally asymmetric SLP (ZA_SLP), estimated as the difference between the SLP at each grid point and the DJF zonal mean. Upper level (200hPa) divergence (Div200) and the $700 \mathrm{hPa}$ and $850 \mathrm{hPa}$ saturation deficits $\left(\mathrm{Q} 700_{\mathrm{d}}\right.$ and $\mathrm{Q} 850_{\mathrm{d}}$, respectively) were also calculated using CFSR. The latter quantifies how far the atmosphere is from saturation, in terms of vapor mass $(\mathrm{g} / \mathrm{kg})$, and is defined for each level as the difference between the saturation specific humidity $\left(\mathrm{Q}_{\text {sat }}\right)$ and the ambient specific humidity (Q) at that level. The $\mathrm{Q}_{\text {sat }}(\mathrm{in} \mathrm{kg} / \mathrm{kg}$ ) was estimated as (Emanuel, 1994):

$$
Q_{s a t}=\frac{\epsilon e_{s a t}}{p-e_{s a t}(1-\epsilon)}
$$

where $p$ is pressure, $\epsilon(=0.62220)$ is the ratio between the gas constant for dry air and for water vapor, and $e_{\text {sat }}$ is the saturation vapor pressure at that level, estimated as (Bolton, 1980):

$$
e_{\text {sat }}=6.112 e^{\left[\frac{17.67 T}{T+243.5}\right]}
$$

where $e_{\text {sat }}$ is in units of $\mathrm{hPa}$ and $T$ is the temperature at that level, in ${ }^{\circ} \mathrm{C}$.

\section{Decadal Changes in the Mean State}

\subsection{Precipitation}

Both the SAMS and SACZ are evident in the GPCP average DJF daily-mean precipitation rate (Fig 1a). Additionally, the seasonal average precipitation in Fig 1a indicates the climatological positions of the Intertropical Convergence Zone (ITCZ) over the equatorial Atlantic and Pacific oceans, as well as the South African Summer Monsoon and the South Pacific Convergence Zone (SPCZ) over the central South Pacific.

The difference between DJF precipitation averaged during the first (1979-91) and last (2005-14) periods (Fig 1b) indicates an area of decreased (increased) precipitation along the equatorward (poleward) margin of the climatological SACZ extending from central Brazil into the subtropical Atlantic ocean, significant along eastern Brazilian coast. For reference, we have included in Fig $1 \mathrm{~b}$ the $5 \mathrm{~mm} /$ day isohyet for each 10-yr period (1979-91, solid red; 1992-04, dot-dashed brown; and 2005-14, dashed black), to 
delineate the climatological location of the SACZ. A similar drying/wetting pattern is observed along the Atlantic ITCZ and over southern Africa, while the SPCZ exhibits a drying trend along both its poleward and equatorward margins. Additionally, there is a region of significant precipitation increase over equatorial western Amazon. These spatial patterns and intensity of changes are robust to the inclusion of ENSO years (not shown).

To highlight the SACZ precipitation differences, we considered a cross-section roughly perpendicular to the NW-SE orientation of the SACZ (between $40^{\circ} \mathrm{S}, 47.5^{\circ} \mathrm{W}$ and $10^{\circ} \mathrm{S}, 30^{\circ} \mathrm{W}$ ) and across the regions with the largest changes in precipitation (Fig 1b). The Hovmöller diagram in Fig 2a represents the average precipitation for each DJF season along this cross-section, while Fig $2 b$ illustrates the mean DJF precipitation for each of the study periods. While there is clearly substantial year-to-year variability, a general shift toward wetter conditions over the poleward margin of the SACZ (south of $30^{\circ} \mathrm{S}$ ) emerges in the early 1990s (Fig 2a). Fig 2b highlights a poleward expansion of the poleward margin of the SACZ during the second period (1992-04) relative to the first period (1979-91). On the equatorward margin of the cross-section (north of $30^{\circ} \mathrm{S}$ ), the drying tendency appears in the mid-2000s (Fig 2a), affecting the average over the last period (2005-14) and shifting precipitation poleward (Fig 2b, dashed black line). Overall, the average position of maximum precipitation along this cross-section has been displaced southward by $\sim 4^{\circ}$ from the late 1970s through the 2010s. The low-frequency evolution of precipitation, more evident after the mid-2000s, indicates that the drying tendency along the SACZ equatorward margin is not simply the effect of the intense drought that affected SE Brazil in 2014/2015 (Otto et al. 2015; Coelho et al. 2016a, b; Nobre et al. 2016). In fact, the behavior seen here over the oceanic portion of the SACZ is broadly consistent with the drying tendency observed since 1998 in the region as documented in Coelho et al. (2016a).

The spatial pattern of precipitation changes shown above resembles the negative phase of SACZ dipole, with the positive (negative) precipitation anomalies over SESA (CEBr) (e.g., Zhou and Lau 1998; Carvalho et al. 2002, 2011; Grimm and Zilli 2009). Grimm and Saboia (2015) demonstrated that precipitation variability associated with the dipolar mode also has a multidecadal component. However, such changes are also consistent with the projected increase in the frequency of the dipole's negative phase arising in historical and future scenarios of anthropogenic climate change (Junquas et al. 2012; Talento and Barreiro 2012; Jones and Carvalho 2013; Diaz and Vera 2017).

\subsection{Temperature and Specific Humidity}

The SAMS circulation is mainly driven by the differential heating between land and ocean and resulting land-ocean pressure gradient (Zhou and Lau 1998). During the period analyzed here, the average temperature at $850 \mathrm{hPa}(\mathrm{T} 850)$ in $\mathrm{DJF}$ has increased over tropical SA and adjacent oceans, whereas subtropical and midlatitude regions have cooled (Fig 3a). Over the tropics, the largest warming has occurred over equatorial and subtropical North Atlantic Ocean basins. Over the tropical North Atlantic warming of SST has also occurred, as exemplified by the northward shift of the $27^{\circ} \mathrm{C}$ isotherm along the northern SA coast during the three consecutive periods (Fig 3b). Similar changes in the spatial 
1 distribution of SSTs are also observed in HadISST data (Fig S1 in the Online Supplementary material).

2 Although the increase in SST over the tropical and subtropical South Atlantic resembles the SAD's

3 spatial pattern, the observed changes in precipitation are not consistent with its impacts. During SAD

4 negative phase, the warming (cooling) of the subtropical (tropical) South Atlantic is associated with an

5 enhancement of SACZ activity resulting in positive (negative) precipitation anomalies over CEBr (SESA)

6 (Bombardi et al. 2013). Our results suggest that the warming of the subtropical South Atlantic is

7 associated with drying over $\mathrm{CEBr}$, opposite to the expected positive precipitation anomalies related to

8 negative SAD phase. Over the tropical South Atlantic, the changes in SST are negligible and not 9 statistically significant (Fig 3b).

10 Moreover, the warming over the southwestern South Atlantic is coherent with the atmosphereocean coupled mode of internal variability described by Talento and Barreiro (2012). According to these authors, negative (positive) precipitation anomalies over CEBr and the oceanic part of the SACZ reduce (increase) cloudiness over the ocean, resulting in positive (negative) SST anomalies over southwestern South Atlantic. In fact, our results suggest a warming of southwestern South Atlantic (Fig 3b and Fig S1) and a reduction of precipitation along the equatorward margin of the SACZ stronger over its oceanic portion (Fig 1b). However, the analysis presented here does not allow us to determine whether changes in SST are forcing precipitation along the equatorward margin of the SACZ or the reduction in cloudiness is warming up the ocean's surface. Positive SST anomalies over southwest South Atlantic have been related to the strengthening of the SASH, shifting the confluence of the warm Brazilian current with the cold Maldives current southward (Wainer and Venegas 2002). progressive warming since 1990 s illustrated by the behavior of the $18^{\circ} \mathrm{C}$ isotherm (Fig $3 \mathrm{a}$ ). Note that the mean (climatological) temperature is above (below) $18^{\circ} \mathrm{C}$ inside (outside) this isotherm (see also Fig S2 in the Online Supplementary Material). At $850 \mathrm{hPa}$, summertime temperature in the tropics and subtropics is largely controlled by cloudiness and precipitation (e.g., McGregor and Nieuwolt 1998). In fact, precipitation has decreased over eastern Amazon and northeastern Brazil (Fig 1b), where the warming has been more intense during the last period (Fig 3a). Conversely, over western Amazon, where precipitation has increased during the last period (Fig 1b), the warming at $850 \mathrm{hPa}$ is less intense (Fig 3a). The warming over tropical SA, also detected when using ERAI (Fig S3), is consistent with previous studies based on historical scenarios of climate change (Carvalho and Jones 2013; de Barros Soares et al. 2017) and cannot be explained by natural climate variability alone (de Barros Soares et al. 2017).

Significant cooling at $850 \mathrm{hPa}$ is observed in the subtropics, coinciding with the climatological position of the semi-permanent anticyclones of the southeastern Pacific and Atlantic oceans (Figs 3a and S3). Cooling is also observed in the storm track over southeastern Pacific and southwestern Atlantic, and over northwestern Argentina. Cooling over these regions is restricted to levels below 500hPa (not shown), which suggests the impact of an increase in cloudiness.

Consistent with the observed tropospheric warming and with Clausius-Clapeyron scaling of moisture saturation, specific humidity has also increased over the monsoonal regions of SA and Africa 
1 increase in specific humidity is not as pronounced, despite the strong warming observed over the region

2 (compare Fig 3a, 4a, and 4b). Over the oceans, the moistening is not uniform with altitude. Interestingly,

3 at $700 \mathrm{hPa}$ (Fig $4 \mathrm{~b}$ ), there is drying of the troposphere equatorward of the SACZ and extending eastward

4 over the tropical South Atlantic; similarly, drying occurs over the tropical Central Pacific to the north of

5 the SPCZ (Fig 4b). Both regions are characterized by subsidence ( $\omega 500$, c.f. Fig 6b, contours) associated

6 with the semi-permanent anticyclones southeastward of each oceanic basin. Changes in specific humidity

7 from ERAI indicate decreased moisture over the tropical South Atlantic in the later period, both at

$8 \quad 850 \mathrm{hPa}$ and 700hPa (Fig S4a and b, respectively), including those regions where CFSR Q850 exhibits

9 moistening. However, both reanalyses agree with an increase (decrease) of available moisture along the poleward (equatorward) margin of the SACZ. These results are further explored in Section 4.

\section{3.3. Circulation and Geopotential Height}

The warming trend of the tropical troposphere can also be seen in the vertical expansion of the troposphere and consequent increase in geopotential heights in the upper troposphere. Fig 5a illustrates this by highlighting the mean 12400gpm isopleth for the three consecutive periods. During 1979-1991 (red solid contour), the 12400gpm isopleth is confined to the Bolivian Altiplano, near the center of the Bolivian High. During 1992-2004, (brown dot-dashed contour), this isopleth encompasses most of tropical SA, while during 2005-2014 (black dashed line) it extends over most of the tropics, between $20^{\circ} \mathrm{N}$ and $20^{\circ} \mathrm{S}$. Similar behavior is observed at upper levels over southern Africa. Even though the vertical expansion of the troposphere in ERAI occurs mostly along the storm tracks (Fig S5a), both CFSR and ERAI show a poleward expansion of subtropical anticyclones over both the South Atlantic and South Pacific oceans (Fig 5b, S5b, and S6). One possible consequence of the vertical expansion of the troposphere is the widening of the Hadley cell, shifting the semi-permanent subtropical high pressure systems and the Southern Hemisphere storm track poleward (Schneider et al. 2010; Seidel and Randel 2007; Vecchi and Soden 2007; Chen et al. 2014). Similar changes in the SASH have been described in studies using the 40-year European Centre for Medium-Range Weather Forecasts Re-Analysis (Li et al. 2013) and in future scenarios of climate change from CMIP3 and CMIP5 models (Lu et al. 2007; Li et al. 2013).

Changes in the SASH affect the intensity of the northerly winds along the eastern Brazilian coast. In fact, the difference between the average summer wind at 850hPa between 1979-91 and 2005-14 shows a cyclonic anomaly over the subtropical South Atlantic Ocean (Fig 6a), consistent with a southwestward expansion of the SASH. The anomalous southerly winds along the western flank of this anomalous circulation reduce the poleward flow over $\mathrm{CEBr}$ and adjacent tropical Atlantic (Fig 6a). Given that the northerlies in this region are related to the position and strength of the SACZ (Kodama, 1992, 1993), a weakening of the meridional wind component is potentially associated with reduced precipitation caused by the weakening of the low-level convergence and ascent ( $\omega 500$; Fig $6 \mathrm{~b})$. This will be examined 

motion has intensified (Fig 6b) along the eastern slope of the tropical Andes. Together with increased specific humidity over the region (Fig 4), the increased low-level flow enhances the poleward moisture flux toward subtropical SA. These results are similar to the changes in climatology projected for the A2 scenario according to HadRM3P regional model described by Soares and Marengo (2009). Along the poleward margin of the SACZ, anomalous westerlies form the northern flank of a cyclonic circulation anomaly centered at about $35^{\circ} \mathrm{S}$ and $56^{\circ} \mathrm{W}$ (Fig 6a), which deflects the moisture flux from the Amazon toward southeastern Brazil and is associated with the enhancement of ascending air (Fig 6b) and convection over the region (Fig 1b). A similar pattern of changes in meridional wind at $850 \mathrm{hPa}$, namely accelerating (decelerating) northerly winds east of the Andes (along eastern Brazilian coast), is also observed in ERAI (Fig S7a). Furthermore, the changes in Wind850 in ERAI suggest a cyclonic anomaly over tropical South Atlantic, related to an expansion of the SASH, and over subtropical South America (Fig S7b).

\section{Impact of Large Scale Changes on Regional Precipitation over Eastern}

\section{Brazil} are maintained by the convergence between the low level poleward flow along the western periphery of subtropical anticyclones and the mid-to-upper level westerlies on the equatorward flank of the subtropical jet. On interannual timescales, stronger low-level poleward (northerly) winds on the equatorward margin (Muza et al. 2009). Our results indicate a weakening of the low level poleward flow (Wind850, Fig 6a) during the latest period (2005-14) along with a decrease in convection over CEBr, as exemplified by reduced precipitation (Fig 1b) and ascent (Fig 6b), and increased temperature at $850 \mathrm{hPa}$ (Fig 3a).

A more detailed analysis of the difference in winds at $850 \mathrm{hPa}$ averaged over the first (1979-91) and last periods (2005-14) is presented in Fig 7a. In this figure, the black arrows represent the average for the last period (2005-14) and red arrows the average for the first period (1979-91). The wind speed weakens along the north and western flanks of the SASH, with the black arrows systematically smaller than and oriented to the right of the red arrows, consistent with an expansion of the SASH. To further investigate the implications of weaker northerlies on precipitation over the equatorward margin of the SACZ, we consider a cross-section along the convective margin (between $12^{\circ} \mathrm{S}, 45^{\circ} \mathrm{W}$ and $35^{\circ} \mathrm{S}, 15^{\circ} \mathrm{W}$, Fig 7a). The Hovmöller diagram along this cross-section (Fig 7b) shows the DJF average of meridional wind at $850 \mathrm{hPa}$ from 1979 to 2014. During the late 1970s-1990s, the maximum wind speed along this cross-section occurred between $41^{\circ} \mathrm{W}$ and $35^{\circ} \mathrm{W}$. After 2000 , the position of the maximum meridional wind moved southeastward, with reduced intensity after 2005. Fig 7c shows the meridional wind and precipitation along this cross-section, averaged over the three periods considered here. The reduction in the meridional wind during the last period $(2005-14)$ between $39^{\circ} \mathrm{W}$ and $34^{\circ} \mathrm{W}$ along the convective margin is as large as $1 \mathrm{~m} / \mathrm{s}$ and corresponds to a decrease in average precipitation of about $1 \mathrm{~mm} / \mathrm{day}$ (Fig 

observed when using ERAI (Fig S8).

The weakening of the northerly winds along the equatorward margin of the SACZ in recent decades is associated with reduced low-level convergence and consequently reduced ascent (Fig 6b), weakening the upper level divergence (at 200hPa, Div200; Fig 8a). The cross-section along the convective margin is located where the climatology for the upper level divergence changes from divergence to the south to convergence to the north (cross-section " $A$ " in Fig 8a). Consequently, the divergence was close to zero along this cross-section until approximately 1990, with a region of small positive values between $41^{\circ} \mathrm{W}$ and $36^{\circ} \mathrm{W}$ near the eastern Brazilian coast (Fig 8b). Since then, the divergence has become consistently negative near the coast, with more intense convergence occurring after 2005. From 2009 until 2014, upper level convergence has dominated over the entire oceanic portion of the cross-section (east of $41^{\circ} \mathrm{W}$, Fig 8b). The average Div200 during each of the three periods (Fig 8c) shows that the area of the cross-section with the largest decrease in divergence coincides with the region with significant reduction in precipitation (Fig 8c).

Changes in Div200 along the equatorward margin of the SACZ suggest a poleward shift in the upper level convergence-divergence boundary, evident in the DJF Div200 averaged across the oceanic portion of the SACZ, along the cross-section "B" in Fig 8a. Until 2005, the transition from convergence to divergence was located near $19^{\circ} \mathrm{S}$ (Fig 8d). After 2005, the convergence-divergence boundary shifted southwestward, accompanying changes in precipitation. The DJF average over each of the periods manifests this shift in both precipitation and Div200 between $24^{\circ} \mathrm{S}$ and $18^{\circ} \mathrm{S}$ (Fig 8e). Over the poleward margin of the SACZ (south of $\sim 32^{\circ} \mathrm{S}$ along the "B" cross-section), the upper level divergence reversed from convergence to divergence in the beginning of the 1990s (Fig 8d and 8e), shifting the convergencedivergence boundary poleward. Consequently, precipitation increased along the poleward margin of the SACZ following the pattern of increased upper level divergence (Fig $8 \mathrm{~d}$ and 8e). These results, particularly the changes observed along the equatorward margin of the SACZ, are strong evidence that the weakening of the winds in the lower troposphere over $\mathrm{CEBr}$ and adjacent ocean has reduced the dynamic support for convection in this region, decreasing precipitation and shifting the convergence southward.

The weakening in the meridional component of the wind along the equatorward margin of the SACZ yields a more zonal orientation of the winds (Fig 7a). In prior work, Lintner and Neelin (2010) constructed composites of rainfall along the equatorward margin of the SACZ indexed on variations in the component of the low-level horizontal wind in the direction of the mean moisture gradient. Building on a simple 1D moisture budget prototype as described in Lintner and Neelin (2007), Lintner and Neelin (2010) argued that this margin is sensitive to variations in low-level inflow owing to the mean moisture gradient that exists between dry descent region over the Atlantic Basin and the moisture regions downstream over South America and the ITCZ. In particular, in their framework, decreasing the strength of along-gradient winds was shown to increase precipitation, owing to decreased ventilation of the convecting region by horizontal advection of low moist static energy air masses originating over the Atlantic. By contrast, the results presented here show a weakening in the meridional component of the 
winds in connection with decreased rainfall along the equatorward margin of the SACZ (Fig 7a). Of course, we should point out that the composite analysis of Lintner and Neelin (2010) did not account for changes in low-level convergence of the flow, which we have shown to be occurring for the decadal scale changes discussed here. It is also clear from Fig 7a that while the meridional component of the flow weakens, the zonal component strengthens.

For further insight, we examined changes in the mean specific humidity between 1979-91 and 2005-14 periods for an atmospheric column along the convective margin (Fig 9). As noted earlier, the profile of changes in specific humidity in the lower troposphere is not uniform (compare Q850, Fig 4a, and Q700, Fig 4b). Considering the cross-section along the equatorward margin of the SACZ ("A" in Fig $4 a)$, precipitation has decreased during the last period (2005-14) compared to the first period (1979-91) along the entire margin (Fig 9, bottom), despite the increase in moisture at $850 \mathrm{hPa}$ (Fig 9, top). In contrast, specific humidity at $700 \mathrm{hPa}$ has decreased along the same cross-section, especially between $43^{\circ} \mathrm{W}$ and $35^{\circ} \mathrm{W}$ (Fig 9, top), or coincident with the region of largest precipitation decrease (Fig 9, bottom, and Fig 2). Changes in specific humidity from ERAI are similar, with the largest drying occurring between $700 \mathrm{hPa}$ and $500 \mathrm{hPa}$ along the convective margin of the SACZ (Fig S9).

To better characterize the relationships between ventilation at $700 \mathrm{hPa}$ and the observed precipitation changes, we estimated changes in the average saturation deficit $\left(Q 700_{d}=Q 700_{\text {sat }}-\right.$ Q700) from the first (1979-91) to the last period (2005-14; Fig 10). Large (small) values of Q700 $\mathrm{d}_{\mathrm{d}}$ are related to a relatively dry (humid) atmosphere. Therefore, positive (negative) differences between the two periods indicate that the atmosphere is moving away from (closer to) saturation.

Between 1979-91 and 2005-14, DJF average Q700 decreased over western and southern Amazon and along the poleward margin of the continental SACZ, and increased over the equatorward margin of the SACZ and over the tropical South Atlantic (Fig 10a). Drying at this level is stronger over the ocean, with larger $\mathrm{Q} 700_{\mathrm{d}}$ during the last period (2005-14) along the entire cross-section at the poleward margin of the SACZ (Fig 10c). The reduction in precipitation during the last period (2005-14) follows the increase in $\mathrm{Q} 700_{\mathrm{d}}$, with larger changes between $39^{\circ} \mathrm{W}$ and $34^{\circ} \mathrm{W}$ (Fig 10c). Similar behavior is observed on the equatorward side of the cross-section across the SACZ, where larger values of Q700 are collocated with more pronounced reduction in precipitation (north of $22^{\circ} \mathrm{S}$, Fig 10e). The Hovmöller diagrams along both cross-sections (Fig 10b and 10d) indicate that the drying along the equatorward margin of the SACZ is stronger after 2005 (Fig 10b), and it has been occurring since the beginning of the 1990s over tropical South Atlantic (north of $18^{\circ} \mathrm{S}$, Fig 10d). However, on the poleward margin of the SACZ, represented as the poleward side of the cross-section across the oceanic SACZ (south of $28^{\circ} \mathrm{S}$ ), precipitation has increased since 1992 but Q700 has remained unchanged (Fig 10d and 10e). Similar analysis at $850 \mathrm{hPa}$ indicates moistening at this level, as represented by reduced $\mathrm{Q} 850_{\mathrm{d}}$ along the oceanic portion of the convective margin (east of $\sim 38^{\circ} \mathrm{W}$; Fig 11a) and across the oceanic SACZ (Fig 11b), with both been stronger after 2005 .

Hence, the reduction in precipitation over $\mathrm{CEBr}$ and adjacent Atlantic Ocean has been occurring since 2005 and is associated with weaker northerly winds, which reduce convergence and ascent over the region. The drying observed at $700 \mathrm{hPa}$ further contributes to reduce precipitation through the advection of 
relatively drier air toward the convective margin, which weakens or even inhibits convective activity due to increased stability. These changes are also observed when using ERAI reanalysis and thus are not an artifact of the reanalysis algorithm.

4

5

6

\section{Conclusions}

During austral summer (DJF), intense precipitation in CEBr is modulated by the SAMS and by the SACZ. In prior work, Zilli et al. (2016) identified a trend toward increased average precipitation and intensity of extreme events over the southern portion of SE Brazil, while further north extreme events have intensified over time but the number of rainy days has decreased. This spatial variability in the lowfrequency precipitation behavior suggests changes in the SACZ's position and intensity. To interpret these changes and identify underlying dynamic and thermodynamic mechanisms, we have examined here decadal changes in the mean state of the atmosphere and ocean in recent years, along with changes in precipitation at the margins of the SACZ.

By comparing GPCP average daily precipitation during DJF for the periods of 1979-1991 and 2005-2014 (excluding strong ENSO years) we identified a reduction in average daily precipitation along the equatorward margin of the SACZ, especially after 2005. Along the poleward margin, we observe an increase in average daily precipitation since $\sim 1992$. Both results are more noticeable over the coastal and oceanic portions of the SACZ and provide evidence of a poleward shift in the SACZ in recent years. This shift partially explains the increase in average precipitation observed over the southern part of SE Brazil (Zilli et al. 2016). The reduction in average precipitation identified here over $\mathrm{CEBr}$ reflects the decreased number of rainy days described in Zilli et al (2016).

Comparison of DJF averages of circulation and thermodynamic variables for the periods of 1979-1991 and 2005-2014 reveals regional changes occurring over SA and adjacent South Atlantic Ocean that have influenced the position and strength of the SACZ. The average circulation features associated with the SACZ, as well as the changes observed in this study, are schematically represented in Fig 12 (top and bottom, respectively). The spatial pattern of warming over the tropics in recent years has modified land-ocean temperature contrasts and sea level pressure gradient, the main drivers of the monsoonal circulation (Zhou and Lau 1998; Rodwell and Hoskins, 2001). The deceleration of the low level winds over tropical South Atlantic suggests an intensification of the SASH (represented in yellow in Fig 12). Changes in various atmospheric fields corroborate with an expansion of the SASH, including the warming of southwestern South Atlantic and the increase in subsidence and in saturation deficit over tropical South Atlantic. As a consequence, cyclonic wind anomalies occur over tropical South Atlantic, weakening of the northerly winds over $\mathrm{CEBr}$ and adjacent ocean (represented in magenta in Fig 12). According to Kodama $(1992,1993)$, the presence of poleward flows on the west flank of a subtropical high is one of the necessary conditions for the establishment of convergence zones in the subtropics. This flow is responsible for advecting moisture and heat from lower latitudes into the convergence zone, increasing instability and convection. The observed weakening of the poleward flow over $\mathrm{CEBr}$ and adjacent Atlantic Ocean identified in this study is associated with reduced low level convergence and 
ascending motion, consequently decreasing upper level divergence along the SACZ convective margin. These changes reduce the dynamic support necessary for convection and precipitation along the equatorward margin of the SACZ, mostly over its oceanic portion.

Conversely, the strengthening of the poleward flow along the eastern flank of tropical Andes favors moisture advection from the Amazon toward SESA. Together with an anomalous cyclonic circulation over SESA, this enhanced flow creates favorable conditions for the increase in precipitation along the poleward margin of the SACZ. Hence, the reduction (enhancement) of dynamic component of the circulation along the equatorward (poleward) margin of the SACZ results in favorable conditions for the poleward shift of the convective zone.

Changes in specific humidity over $\mathrm{CEBr}$ and adjacent ocean are further consistent with a reduction in the average precipitation there. Even though the atmosphere has become more humid at $850 \mathrm{hPa}$, it has dried at $700 \mathrm{ha}$ and $500 \mathrm{hPa}$ (brown area in Fig 12). The reduction in specific humidity at $700 \mathrm{hPa}$ and the increase in the saturation deficit could be indicative of increase in subsidence along the northern flank of the SASH. As shown by Lintner and Neelin (2010), the flow into the equatorward margin of the SACZ originates mainly from the tropical South Atlantic, a region of relatively high stability. We speculate that drying of the $700 \mathrm{hPa}$ layer, which is more pronounced over the source region of flow toward the SACZ, reduces moisture transport into the convective margin, increasing the local saturation deficit and contributing to the reduction in precipitation and in the number of rainy days identified in Zilli et al. (2016). The drier environment at $700 \mathrm{hPa}$ may act to inhibit the growth of deep convection via entrainment. Nevertheless, the presence of a drier layer atop of a moist layer may increase convective instability; therefore, when conditions favor convective development, these conditions may lead to more intense deep convection and extreme precipitation. Indeed, this may account for the increasing intensity of extreme events observed in Zilli et al. (2016). A more detailed investigation of the air parcels trajectory toward the SACZ and changes in local thermodynamics is necessary to assess the role of drying at $700 \mathrm{hPa}$.

Overall, the results presented here provide evidence that precipitation changes along the equatorward margin of the SACZ, especially its oceanic portion, are likely related to a poleward shift of the convergence zone, caused primarily by the weakening of the northerly winds along the western flank of the SASH and drying of low-to-mid troposphere $(700 \mathrm{hPa})$ along the equatorward margin of the SACZ (Fig 12, bottom). Similar results were identified using ERAI, suggesting that changes are not an artifact of the data assimilation or reforecasting process (Supplementary Online material). Based on these results, we suggest that changes in the SACZ could be related to changes in the positioning and intensity of the SASH. Moreover, the warming of the southwestern South Atlantic further corroborates with a southwestward shift of the SASH and consequent changes in the Hadley circulation.

Despite the robustness of these results in two different reanalyses, the time series considered are not long enough to define the causes of the described changes or if these changes will persist in the future. A more detailed analysis of heating sources and their impacts on the regional circulation are necessary to determine whether these changes are part of natural variability or forced by anthropogenic-related climate change (or a combination of both). Previous studies suggest that changes in SST over southwestern South 
1 Atlantic is part of a multidecadal variability mode with period of 25-30 years (Wainer and Venegas

2 2002), with positive anomalies related to drying over the SACZ, mostly on its oceanic portion (Barreiro et

3 al. 2002; Talento and Barreiro 2012). Furthermore, variations in the dipolar structure of the SACZ can be

4 modulated by coupled climatic modes on decadal to multidecadal time-scales (e.g., Grimm and Saboia,

5 2015). Also relevant, circulation and precipitation changes diagnosed here are consistent with coupled

6 climate model projections under future scenarios of climate change (Seth et al. 2010; Talento and

7 Barreiro 2012; Junquas et al. 2012; Carvalho and Jones 2013; Li et al 2013, Diaz and Vera 2017). Thus,

8 the relatively short length of records (36 years) restricts the ability of this study to investigate the

9 influence of low-frequency climatic modes such as the PDO and AMO, or attribute these observed

10 changes to anthropogenic forcing. Whether resulting from anthropogenic forcing or modulated by

11 coupled climate models (or from a combination of both), these changes need to be further investigated to

12 increase resilience and assist with decision-making.

\section{Acknowledgments}

GPCP Precipitation data was provided by the NOAA/OAR/ESRL PSD, Boulder, Colorado, USA, from their Web site at http://www.esrl.noaa.gov/psd/. NOAA High Resolution SST data was provided by the NOAA/OAR/ESRL PSD, Boulder, Colorado, USA, from their Web site at http://www.esrl.noaa.gov/psd/. M. Zilli acknowledges the Brazilian National Council for Scientific and Technological Development $(\mathrm{CNPq})$ for the financial support through the Science without Borders Program (202691/2011-0). L. Carvalho acknowledges the São Paulo Research Foundation (FAPESP) Proc. 2008/58101-9. L. Carvalho and B. Lintner acknowledge the support of NSF-AGS-1505198.

\section{References}

Barreiro M, Chang P, Saravanan R (2002) Variability of the South Atlantic Convergence Zone Simulated by an Atmospheric General Circulation Model. J Clim 715:745-763

Barros V, Doyle M, Camilloni I (2008) Precipitation trends in southeastern South America: relationship with ENSO phases and with low-level circulation. Theor Appl Climatol 93:19-33. doi: 10.1007/s00704007-0329-X

Barros V, Gonzalez M, Liebmann B, Camilloni I (2000) Influence of the South Atlantic Convergence Zone and South Atlantic sea surface temperature on interannual summer rainfall variability in Southeastern South America. Theor Appl Climatol 67:123-133

Bolton D (1980) Computation of equivalent potential temperature. Mon Weather Rev, 108:1046-1053

Bombardi RJ, Carvalho LMV, Jones C, Reboita MS (2013) Precipitation over Eastern South America and the South Atlantic Sea surface temperature during neutral ENSO periods. Clim Dyn 42:1553-1568. doi: 10.1007/s00382-013-1832-7

Carvalho LMV, Jones C (2013) CMIP5 simulations of low level tropospheric temperature and moisture over tropical Americas. J Clim 26:6257-6286. doi: 10.1175/JCLI-D-12-00532.1 
Carvalho LMV, Jones C, Liebmann B (2002) Extreme precipitation events in Southeastern South 2 America and large-scale convective patterns in the South Atlantic Convergence Zone. J Clim 15:2377$3 \quad 2394$

4 Carvalho LMV, Jones C, Liebmann B (2004) The South Atlantic Convergence Zone: intensity, form, 5 persistence and relationships with intraseasonal to interannual activity and extreme rainfall. J Clim 17:886108

7 Carvalho LMV, Silva AE, Jones C, Liebmann B, Silva Dias PL, Rocha HR (2011) Moisture transport and 8 intraseasonal variability in the South America Monsoon System. Clim Dyn 36:1865-1880. doi: 9 10.1007/s00382-010-0806-2

10 Chen S, Wei K, Chen W, Song L (2014) Regional changes in the annual mean Hadley circulation in recent decades. J Geophys Res: Atmosph 119:7815-7832. doi: 10.1002/2014JD021540

Coelho CAS, Cardoso DHF, Firpo MAF (2016a): Precipitation diagnostics of an exceptionally dry event in São Paulo, Brazil. Theor Appl Climatol. doi: 10.1007/s00704-015-1540-9

Coelho CAS, Oliveira CP, Ambrizzi T, Reboita MS, Carpenedo CB, Campos JLPS, Tomaziello ACN, Pampuch LA, Custódio MS, Dutra LMM, Rocha RP, Rehbein A (2016b) The 2014 Southeast Brazil austral summer drought: regional scale mechanisms and teleconnections. Clim Dyn 46:3737-3752. doi: $10.1007 / \mathrm{s} 00382-015-2800-1$

Dee DP, Uppala SM, Simmons AJ et al (2011) The ERA-Interim reanalysis: configuration and performance of the data assimilation system. Q J Royal Meteorol Soc 137:553-597. doi: 10.1002/qj.828

de Barros Soares D, Lee H, Loikith PC, Barkhordarian A, Mechoso CR (2017) Can significant trends be detected in surface air temperature and precipitation over South America in recent decades? Int J Climatol 37:1483-1493. doi:10.1002/joc.4792

Díaz LB, Vera CS (2017) Austral summer precipitation interannual variability and trends over Southeastern South America in CMIP5 models. Int J Climatol 37:681-695. doi: 10.1002/joc.5031

Drumond ARM, Ambrizzi T (2006) Inter-ENSO variability and its influence over the South American Monsoon System. Adv Geosci 6:167-171. Emanuel KA (1994) Atmospheric Convection. Oxford University Press, New York.

Grimm AM (2003) The El Niño impact on the summer monsoon in Brazil: regional processes versus remote influences. J Clim 16: 263-280

Grimm AM, Pal JS, Giorgi F (2007) Connection between spring conditions and peak summer monsoon rainfall in South America: role of soil moisture, surface temperature and topography in eastern Brazil. J Clim 20:5929-5945. doi: 10.1175/2007JCLI1684.1

Grimm AM, Saboia J (2015) Interdecadal variability of the South American precipitation in the monsoon season. J Clim 28:755-775. doi: 10.1175/JCLI-D-14-00046.1

Grimm AM, Zilli MT (2009) Interannual variability and seasonal evolution of summer monsoon rainfall in South America. J Clim 22:2257-2275. doi: 10.1175/2008JCLI2345.1

Haylock MR, Peterson TC, Alves LM et al (2006) Trends in total and extremes South American rainfall in 1960-2000 and links with sea surface temperature. J Clim 19:1490-1512. doi: 10.1175/JCLI3695.1

39 Huffman GJ, Adler RF, Bolvin DT, Gu G (2009) Improving the global precipitation record: GPCP 40 Version 2.1. Geophys Res Lett 36:L17808. doi:10.1029/2009GL040000

41 Jones C, Carvalho LMV (2013) Climate change in the South American Monsoon System: present climate 42 
Junquas C, Vera C, Li L, LeTreut H (2012) Summer Precipitation Variability over Southeastern South

2 America in a Global Warming Scenario. Clim Dyn 38:1867-1883. doi: 10.1007/s00382-011-1141-y

3 Junquas C, Vera CS, Li L, LeTreut H (2013) Impact of Projected SST Changes on Summer Rainfall in 4 Southeastern South America. Clim Dyn 40:1569-1589. doi: 10.1007/s00382-013-1695-y

5 Kitoh A, Endo H, Kumar K, Cavalcanti I, Goswami P, Zhou T (2013) Monsoons in a changing world: a 6 regional perspective in a global context. J Geophys Res - Atmos, 118:3053-3065. doi: 10.1002/jgrd.50258

7 Kodama YM (1992) Large-scale common features of subtropical precipitation zones (the Baiu Frontal 8 Zone, the SPCZ and the SACZ) Part I: characteristics of subtropical frontal zones. J Meteor Soc Japan $9 \quad 70: 813-835$

10 Kodama YM (1993) Large-scale common features of subtropical convergence zones (the Baiu Frontal 11 Zone, the SPCZ and the SACZ). Part II: conditions of the circulations for generating the STCZs. J Meteor 12 Soc Japan 75:581-610

13 Krishnamurthy V, Misra V (2010) Observed ENSO teleconnection with the South American Monsoon System. Atmos Sci Lett 11:7-12. doi: 10.1002/asl.245

Li W, Li L, Ting M, Deng Y, Kushnir Y, Liu Y, Lu Y, Wang C, Zhang P (2013) Intensification of the Southern Hemisphere summertime subtropical anticyclones in a warming climate. Geophys Res Lett 40:5959-5964. doi: 10.1002/2013GL058124

Liebmann B, Jones C, Carvalho LMV (2001) Interannual variability of daily extreme precipitation events in the state of São Paulo, Brazil. J Clim 14:208-218

Lintner BR, Neelin JD (2007) A prototype for convective margin shifts. Geophys Res Lett 34:L05812. doi: 10.1029/2006GL027305

Lintner BR, Neelin JD (2010) Tropical South America-Atlantic sector convective margins and their relationship to low-level inflow. J Clim 23:2671-2685. doi: 10.1175/2009JCLI3301.1

Lu J, Vecchi GA, Reichler T (2007) Expansion of the Hadley cell under global warming. Geophys Res Lett 34:L06805. doi: 10.1029/2006GL028443.

Marengo JA, Liebmann B, Grimm AM, Misra V, Silva Dias PL, Cavalcanti I, Carvalho LM, Berbery E, Ambrizzi, T, Vera C, Saulo A, Nogues-Paegle J, Zipser E, Seth A, Alves L (2012) Review: recent developments on the South American Monsoon System. Int J Climatol 32:1-21. doi: 10.1002/joc.2254

McGregor GR, Nieuwolt S (1998) Tropical Climatology: An Introduction to the Climates of the Low Latitudes, $2^{\text {nd }}$ edition. Wiley, New York, NY.

Muza MN, Carvalho LMV, Jones C, Liebmann B (2009) Intraseasonal and interannual variability of extreme dry and wet events over Southeastern South America and the Subtropical Atlantic during austral summer. J Clim 22:1682-1699. doi: 10.1175/2008JCLI2257.1

Nobre CA, Marengo JA, Seluchi ME, Cuartas LA, Alves LM (2016) Some characteristics and impacts of the drought and water crisis in Southeastern Brazil during 2014 and 2015. J Water Resour Prot 8:252-262. doi: 10.4236/jwarp.2016.82022

Nogues-Paegle J, Byerle LA, Mo KC (2000) Intraseasonal modulation of South American summer precipitation. Mon Weather Rev 128:837-850

Otto FEL, Coelho CAS, King A, Coughlan de Perez E, Wada Y, van Oldenborgh GJ, Haarsma R, Haustein K, Uhe P, van Aalst M, Aravequia JA, Almeida W, Cullen H (2015) Factors other than climate change, main drivers of 2014/15 water shortage in Southeast Brazil. Bull Amer Meteorol Soc 96:S35S40. doi:10.1175/BAMS-EEE_2014_ch8.1 

Global analyses of sea surface temperature, sea ice, and night marine air temperature since the late nineteenth century. J Geophys Res 108:D14. doi: 10.1029/2002jd002670

Reynolds RW, Smith TM, Liu C, Chelton DB, Casey KS, Schlax MG (2007) Daily high-resolutionblended analyses for sea surface temperature. J Clim 20:5473-5496. doi: 10.1175/2007JCLI1824.1

Robertson AW, Mechoso CR (2000) Interannual and Interdecadal Variability of the South Atlantic Convergence Zone. Mon Weather Rev 128:2947-2957

Rodwell MJ, Hoskins BJ (2001) Subtropical anticyclones and summer monsoons J Clim 14:3192-3211

Saha S, Moorthi S, Pan HL et al (2010) The NCEP Climate Forecast System Reanalysis. Bull Am Meteor Soc 91:1015-1057. doi: 10.1175/2010BAMS3001.1

Schneider T, O'Gorman PA, Levine XJ (2010) Water vapor and the dynamics of climate changes. Rev Geophys 48:RG3001. doi:10.1029/2009RG000302

Seidel DJ, Randel WJ (2007) Recent widening of the tropical belt: Evidence from tropopause observations. J Geophys Res 112:D20113. doi:10.1029/2007JD008861

Seth A, Rojas M, Rauscher SA (2010) CMIP3 project changes in the annual cycle of the South American Monsoon. Climatic Change 98:331-357. doi: 10.1007/s10584-009-9736-6

Skansi MM, BrunetM, Sigró J et al (2013) Warming and wetting signals emerging from analysis of changes in climate extreme indices over South America. Glob Planet Change 100:295-307. doi: 10.1016/j.gloplacha.2012.11.004

Soares WR, Marengo JA (2009) Assessments of moisture fluxes east of the Andes in South America in a global warming scenario. Int J Climatol 29:1395-1414. doi: 10.1002/joc. 1800

Talento S, Barreiro M (2012) Estimation of natural variability and detection of anthropogenic signal in summertime precipitation over South America. Adv Meteorol. doi: 10.1155/2012/725343

Talento S, Barreiro M (2017) Control of the South Atlantic Convergence Zone by extratropical thermal forcing. Clim Dyn. doi: 10.1007/s00382-017-3647-4

Vecchi GA, Soden BJ (2007): Global Warming and the Weakening of the Tropical Circulation. J Clim 20:4316-4340. doi: 10.1175/jcli4258.1

Venegas SA, Mysak LA, Straub DN (1997) Atmosphere-Ocean Coupled Variability in the South Atlantic. J Clim 10:2904-2920. doi: 10.1175/1520-0442(1997)010<2904:AOCVIT>2.0.CO;2

Vera C, Higgins W, Amador J, Ambrizzi T, Garreaud R, Gochis D, Gutzler D, Letternmater D, Marengo JA, Mechoso CR, Nogués-Paegle J, Silva Dias PL, Zang C (2006) Toward a unified view of the American Monsoon System. J Clim 19:4977-5000. doi: 10.1175/JCLI3896.1

Wainer I, Venegas SA, (2002) South Atlantic Multidecadal Variability in the Climate System Model. J Clim 15:1408-1420

Wilks DS. 2011. Statistical Methods in the Atmospheric Sciences, Vol. 100. Academic Press: San Diego, CA.

Zhou J, Lau KM (1998) Does a monsoon climate exist over South America? J Clim 11:1020-1040

Zhou J, Lau KM (2001) Principal modes of interannual and decadal variability of summer rainfall over South America. Int J Climatol 21:1623-1644. doi: 10.1002/joc.700

Zilli MT, Carvalho LMV, Liebmann B, Silva Dias MA (2016) A comprehensive analysis of trends in extreme precipitation over southeastern coast of Brazil. Int J Climatol. doi: 10.1002/joc.4840 
Table 1 First year, last year, number of years (\#Yr), and years excluded due to strong ENSO events (EN - El Niño; LN - La Niña) on each period considered for each dataset (GPCP, CFSR, and NOAA OI SST V2)

\section{Figures}

Fig 1 GPCP DJF precipitation rate (mm/day): (a) Climatology for 1979-2014 (contours each 2mm/day); (b) Difference between the first (1979-91) and last (2005-14) periods, with positive (negative) differences in green (brown) and significant difference $(\mathrm{p}<0.05)$ stippled. Contours at the $5 \mathrm{~mm} /$ day isohyet for each period (1979-91, solid red; 1992-04, dot-dashed brown; and 2005-14, dashed black, excluding strong ENSO years). Bold gray line: location of the oceanic SACZ cross-section.

Fig 2 GPCP DJF precipitation rate (mm/day) along the oceanic SACZ cross-section (bold gray line in Fig 1b): (a) Hovmöller diagram, with averages for all grid points along the cross-section and white " $x$ " symbols indicating the latitude of maximum precipitation per season; gray dashed lines separate each period considered. (b) Average for each of the three periods (1979-91, solid red; 1992-04, dotdashed brown; and 2005-14, dashed black). Gray shades show grid points with statistically significant $(\mathrm{p}<0.05)$ differences in precipitation average between first and last periods

Fig 3 Difference in DJF average between first (1979-91) and last (2005-14) periods (shades), with positive (negative) differences in red (blue) and significant differences $(\mathrm{p}<0.05)$ stippled, and DJF average (contours) for each period (1979-91, solid red; 1992-04, dot-dashed brown; and 2005-14, dashed black): (a) T850 (in ${ }^{\circ} \mathrm{C}$ ), contours at $18^{\circ} \mathrm{C}$; and (b) SST (in ${ }^{\circ} \mathrm{C}$ ), contour at $27^{\circ} \mathrm{C}$

Fig 4 Difference in DJF average between first (1979-91) and last (2005-14) periods (shades), with positive (negative) differences in green (brown) and significant differences $(\mathrm{p}<0.05)$ stippled, and climatology for 1979-2014 (contours each $1 \mathrm{~g} / \mathrm{kg}$ ). Bold gray lines: location of the cross-sections along the equatorward margin of the SACZ ("A") and across the oceanic SACZ ("B"). (a) Q850 (in $\mathrm{g} / \mathrm{kg}$ ); and (b) Q700 (in $\mathrm{g} / \mathrm{kg}$ )

Fig 5 Difference in DJF average between first (1979-91) and last (2005-14) periods (shades), with positive (negative) differences in red (blue) and significant differences ( $<<0.05)$ stippled. (a) Z200 (in gpm), contours at 12400gpm representing the DJF average for each period (1979-91, solid red; 1992-04, dot-dashed brown; and 2005-14, dashed black); (b) ZA_SLP (in hPa), with contours representing the DJF climatology (1979-2014; contours each 1hPa, with negative values dashed)

Fig 6 Difference in DJF average between first (1979-91) and last (2005-14) periods (shades), with positive (negative) differences in red (blue): (a) Wind850 (in m/s): wind speed (shades) and vectors (arrows); only areas with significant differences $(\mathrm{p}<0.05)$ for at least one component plotted. (b) $\omega 500(\mathrm{in} \mathrm{Pa} / \mathrm{s})$, with $)$ and significant differences $(\mathrm{p}<0.05)$ stippled and contours representing the DJF climatology (1979-2014; contours each 0.02Pa/s, with negative values dashed)

Fig 7 Wind at $850 \mathrm{hPa}$ (in m/s): (a) Arrows: DJF average during the first (red, 1979-91) and last (black; 2005-14) periods; shades: positive (red) and in negative (blue) significant $(\mathrm{p}<0.05)$ differences between DJF average wind speed for the first (1979-91) and last (2005-14) periods. Bold gray line: location of the cross-section along the equatorward margin of the SACZ. (b) Hovmöller diagram of the average meridional wind for all grid points along the cross-section in (a) with positive (negative) differences in red (blue); gray dashed lines dividing each of the periods considered. (c) Average 
meridional wind (red, brown, and black lines) and precipitation (blue lines with circles marking the center of each grid point, right y-axis) for each period (1979-91, solid; 1992-04, dot-dashed; and 2005-14, dashed) along the cross-section in (a). Shaded areas: grid points with significant $(\mathrm{p}<0.05)$ difference between average precipitation for the first (1979-91) and last periods (2005-14)

Fig 8 (a) As in Fig 6b for Div200 (contours each $1 \times 10^{6} / \mathrm{s}$, negative values dashed). Bold gray lines: location of the cross-sections along the equatorward margin of the SACZ ("A") and across the oceanic SACZ ("B"). (b-e) As in Fig 7b-c for Div200 along the cross-sections in (a): (b-c) averages for the cross-section along the equatorward margin of the SACZ ("A"); and (d-e) averages for the cross-section across the oceanic SACZ ("B")

Fig 9 Difference in DJF averages between first (1979-91) and last (2005-14) periods for all grid points along the equatorward margin of the SACZ (cross-section "A" in Fig 4). Top: vertical profile of specific humidity (in $\mathrm{g} / \mathrm{kg}$ ), with positive (negative) differences in green (brown). Bottom: Precipitation (in $\mathrm{mm} / \mathrm{day}$ ), with circles marking the center of each grid point and shaded areas where the difference is statistically significant $(\mathrm{p}<0.05)$

Fig 10 Q700d (in g/kg): (a) Difference in DJF average between first (1979-91) and last (2005-14) periods (shades), with positive (negative) differences brown (green), significant differences $(\mathrm{p}<0.05)$ stippled, and contours representing the DJF climatology (1979-2014; contours each 1g/kg). Bold gray lines: location of the cross-sections along the equatorward margin of the SACZ ("A") and across the oceanic SACZ ("B"). (b-e) As in Fig 7b-c, along the cross-sections in (a), with positive (negative) differences in brown (green): (b-c) averages for the cross-section along the equatorward margin of the SACZ ("A"); and (d-e) averages for the cross-section across the oceanic SACZ ("B")

Fig 11 DJF average for Q850 (in g/kg), as in Fig 7c, along the cross-sections in Fig 4a: (a) averages for the cross-section along the equatorward margin of the SACZ ("A"); and (b) averages for the crosssection across the oceanic SACZ ("B")

Fig 12 Schematic main features related to the SACZ (top) and changes observed during the last period (2005-14, bottom). Changes in the thickness of the arrows represent relative intensity. Top: climatological position of the SACZ (blue), SASH (yellow), and poleward flow at the western flank of the SASH (magenta). Other features related to the convergence and precipitation at the SACZ: subsidence over tropical South Atlantic (brown), the Chaco Low (purple), and the northerly winds east of the tropical Andes (green), advecting moisture from the Amazon. Bottom: changes in mean state of the atmosphere resulting in a southwestward shift of the SACZ; long-dashed line represents the climatological position of the SACZ (blue), SASH (yellow), and of the flow around the SASH (magenta). Intensification of the SASH (yellow), weakening of the circulation around it (magenta), and a reduction of the specific humidity of tropical South Atlantic (brown) contribute to the poleward shift in the SACZ (blue) and the reduction of precipitation along its equatorward margin (red). Changes in the SASH also affect the northerly winds east of the tropical Andes (green) and respective changes in precipitation in the poleward margin of the SACZ (blue) 